\title{
Hong Kong's first Professor of Pathology and the laboratory of the Royal College of Physicians of Edinburgh
}

\author{
FCS Ho \\ Chairman, Education and Research Committee, Hong Kong Museum of Medical Sciences Society, and Former Professor of Pathology, \\ University of Hong Kong, Hong Kong
}

\begin{abstract}
At a time when the role of the laboratory in clinical medicine and in medical research was evolving rapidly, a young Chinese graduate of the Hong Kong College of Medicine and the University of Edinburgh undertook a period of intensive training at the laboratory of the Royal College of Physicians of Edinburgh that was to play a pivotal role in determining his future career as the first Professor of Pathology at the University of Hong Kong and its first professor of Chinese descent. Chung Yik Wang's subsequent achievements over a span of ten years were a testament to the solid foundation that had been laid during that early period, and was an excellent example of how the skills of medical science could be transferred across continents to best effect. Tragically, Wang's career was cut short when he succumbed to tuberculosis, the disease he had spent many years studying.
\end{abstract}

Correspondence to FCS Ho, clo Hong Kong Museum of Medical Sciences, 2 Caine Lane, Mid-Levels, Hong Kong

tel. +85225495 I 23

e-mail ho.faith@gmail.com

KEYWORDS Hong Kong, laboratory medicine, pathology, RCPE, University of Edinburgh, Chung Yik Wang

DECLARATION OF INTERESTS No conflict of interests declared.

\section{BACKGROUND}

The many links in medicine between Edinburgh and Hong Kong are well recognised, but the story of how one such link was instrumental in paving the way for the development of an academic specialty in Hong Kong is less well known. This link was forged between Professor Chung Yik Wang, the first Professor of Pathology at the University of Hong Kong, and the Royal College of Physicians of Edinburgh (RCPE) or, more specifically, its laboratory. This is all the more remarkable because laboratory medicine as an academic specialty was still in its infancy at the beginning of the twentieth century. This was the period when Wang started his research career at the laboratory of the RCPE and when he subsequently took up the Chair of Pathology at the University of Hong Kong in 1920, the first Chinese to hold a chair at a university in Hong Kong.

Wang was born in Hong Kong in 1888, one year after the RCPE started what was described as the first laboratory for medical research to be established in Britain'. ${ }^{1,2}$ This was a visionary initiative on the part of the Edinburgh College, as there were hardly any facilities available at that time for physicians to pursue a research interest that required laboratory support, even though the value of laboratory experimentation in advancing medical knowledge was gaining increasing prominence. ${ }^{3,4}$ The laboratory of the RCPE (Figure I) was open to all Fellows and Members of the College who could apply to

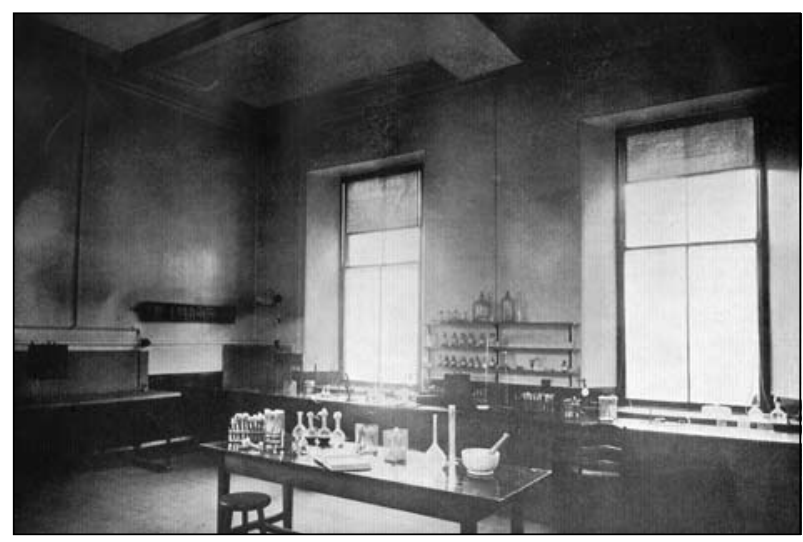

FIGURE I The bacteriology room on the first floor of the Royal College of Physicians of Edinburgh (RCPE) laboratory at 2 Forrest Road. It was connected to a preparation room and a photographic room. (RCPE Sibbald Library collection.)

conduct independent research in the laboratory on a part-time basis in a field of their own interest, while still engaged in their clinical practice. It was also open without fee to 'any Medical Man or Investigator who shall obtain the sanction of the Council of the College, as well as of the Curator and Committee to use the Laboratory for purposes of Scientific Research.' Apart from providing research facilities for physicians free of charge, it also provided a reporting service in pathology and bacteriology for practitioners who wished to avail themselves of the service.' Initially situated at 7 Lauriston 
Lane close to the Edinburgh Royal Infirmary, it moved in May 1896 to 2 Forrest Road. Figure I shows the bacteriology room of the laboratory.

The beginning of the twentieth century, the last years of the Qing dynasty and of imperial rule in China, was a watershed period in Chinese history. Among the younger generation especially, there was increasing interest in all things modern and in science in particular, an interest shared by the Chinese in Hong Kong (then under British rule) and in mainland China. The story of Wang's life is set in this period of history, a seminal period in the interchange of knowledge and skills between East and West.

\section{FAMILY AND EARLY YEARS}

Wang had attended Queen's College in Hong Kong for his secondary schooling and, before arriving in Edinburgh in 1908, had spent five years studying at the Hong Kong College of Medicine (HKCM), which was the only tertiary-level educational institution in Hong Kong at that time. The licence awarded to graduates of the HKCM was, however, not recognised by the General Medical Council. As a consequence, he was not considered eligible for medical registration in Hong Kong, and could not qualify for government medical officer posts nor practise on the same footing as fully registered practitioners. This was the situation before the HKCM was incorporated into the new University of Hong Kong in 1912 as its medical faculty. The College's most famous graduate was Dr Sun Yat-sen, ${ }^{5}$ who was taught by such well-known personalities as Sir Patrick Manson and Sir James Cantlie and in 1892 graduated with the Licentiate in Medicine and Surgery, College of Medicine for Chinese, Hong Kong, as one of only two initial graduates.

The desire to obtain a registrable qualification must have been Wang's primary incentive for making the long journey to Edinburgh to enrol in the MB ChB course.Yet it is clear that he was also motivated by a genuine curiosity to learn more about scientific and technological advances in the major centres of medical education in the West. Besides, three of his elder brothers were already in Europe at that time. Chung Hing Wang was pursuing medical studies at Edinburgh University, while Chung Hui Wang had completed his law studies in the US and in Britain and had just been called to the Bar at Lincoln's Inn, London. For an educated Chinese youth at the beginning of the twentieth century to be able to travel overseas to gain wider experience, especially in the scientific field, was an aspiration that was widespread but not easily realised. Chung Yik Wang was the first of the HKCM graduates to embark on this journey. Wang's father had died when he was 15 years old, and it was his grandfather, Yuen-Sum Wang, already in his nineties, who wrote to his grandsons in Britain, commending their youngest brother to their care. ${ }^{6}$
The Wang family was exceptional in many ways. YuenSum Wang had arrived in Hong Kong in 1845 from the neighbouring Guangdong province in China, soon after Hong Kong became a British colony, and was the first of the Wang family to convert to Christianity when he came under the influence of the early missionary and linguist, Rev. Karl Gützlaff. Thereafter he returned to Guangdong as a missionary for the Rhenish Mission, facing tremendous persecution in so doing. Chung Yik Wang's father, the Rev. Yuk Cho Wang, was the first minister of To Chai Church, an independent Chinese Church in Hong Kong, affiliated to the London Missionary Society. The church was situated on a plot of land adjacent to the Alice Memorial Hospital, where the HKCM was located. Rev. Wang had been a mentor of Sun Yat-sen, while he was studying in Hong Kong, and a supporter of his revolutionary cause. Several of Rev. Wang's seven sons were to make important contributions to the modernisation and development of early republican China.

\section{STUDIES AND EARLY CAREER IN EDINBURGH}

Having been exempted from a significant portion of the course because of his earlier studies at the HKCM, Chung YikWang graduated MB, ChB from the University of Edinburgh in 1910 after only two years of study. He went on to take the Edinburgh Diploma of Tropical Health and Hygiene in 1911, the Diploma of Public Health at Manchester in 1912, and the BSc in Bacteriology and Comparative Pathology in 1913, also in Manchester. It appears from this early stage that Wang's interest lay in scientific research rather than in more clinically orientated specialties.

In November 1913 Wang's name first appeared as one of the laboratory's researchers in the monthly reports of the Superintendent of the RCPE laboratory. ${ }^{7} \mathrm{He}$ continued to work in this same laboratory on a number of different projects until December 1919, but both the first and last mentions of his name in the monthly reports show that he was engaged in research in the field of tuberculosis. During this period he was working in the laboratory on a full-time basis, supported by a McGunn Research Scholarship, a Carnegie Research Fellowship and the Freeland Barbour Fellowship of the RCPE.

From 1913 until 1916 he worked on tuberculosis in the Scottish population, studying sputum specimens sent to the RCPE laboratory as well as specimens from postmortems and from operations conducted at the Royal Infirmary of Edinburgh and the Royal Hospital for Sick Children. For his thesis, 'A study in some phases of tuberculosis, with special reference to the incidence of bovine infection and the question of latency and prevalence of the disease' (a copy of which is stored in the University of Edinburgh Library Archives), he was awarded the MD with a gold medal from the University of Edinburgh in 1916 (Figure 2). Tuberculosis research became his life-long 


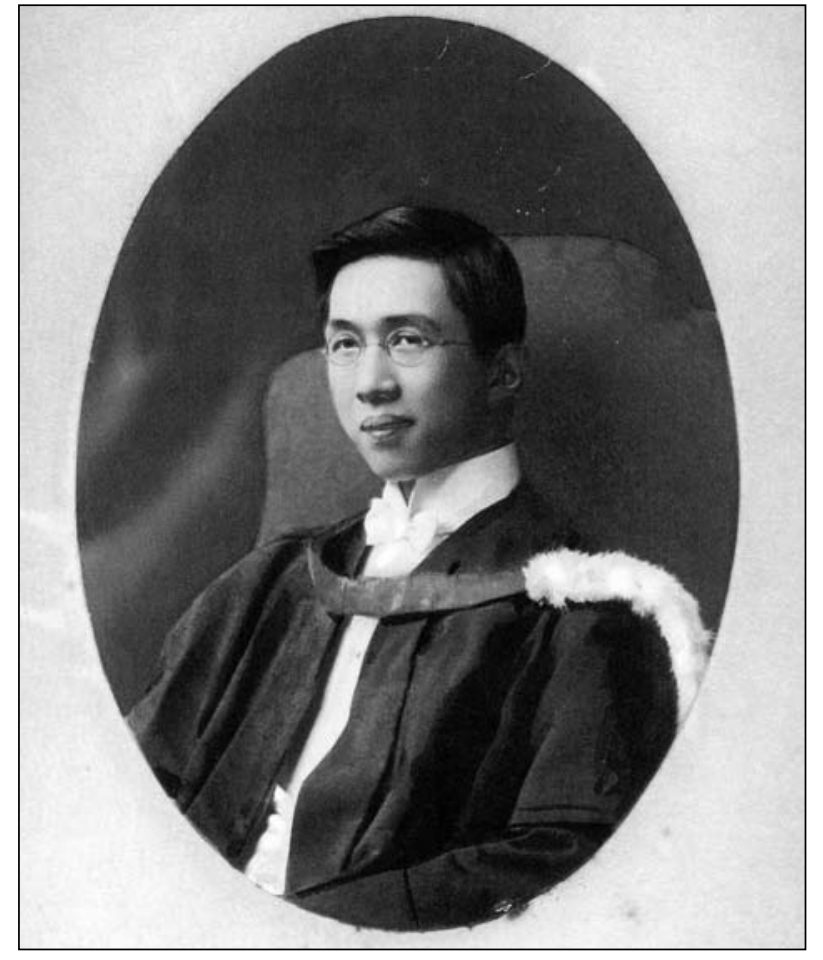

FIGURE 2 Chung Yik Wang in his MD graduation robes, 1916. (With kind permission of the Hong Kong Museum of Medical Sciences Society.)

interest, for which he paid dearly when he succumbed to the disease at the height of his career.

James Ritchie, who had been Professor of Pathology at the University of Oxford, was appointed superintendent of the RCPE laboratory in 1907. When Ritchie was subsequently appointed to the Chair of Bacteriology at the University of Edinburgh in 1913 , the university agreed to reimburse the College the sum of $£ 200$ so that he could continue to use the RCPE laboratory for research.' The Council of the RCPE in turn requested Professor Ritchie retain the title of Superintendent of the College Laboratory. An Assistant Superintendent was appointed to oversee the day-to-day work, both in the reporting section as well as the research section.

When, at short notice, the Assistant Superintendent Dr McGowan was called to military duty during the First World War, the Laboratory Committee appointed Wang interim Assistant Superintendent. In this capacity, Wang assumed responsibility for the general running of the laboratory, for reporting on the many types of specimens submitted for clinical diagnosis (about 4,000-5,000 annually), ${ }^{7}$ as well as continuing with his research and supervising the various public health investigations with which the laboratory was entrusted during the two-year period between 1917 and 1919. The latter included handling specimens from the influenza pandemic, which had spread to Scotland in 1918, and diagnostic work in venereal diseases for the Corporation of Edinburgh in connection with Public Health (Venereal Diseases) regulations.
All this provided Wang with an unrivalled range of experience in clinical and research laboratory work, extending to the field of public health. This was evident from the stream of papers from his pen during this period, describing not only work on his main field of investigation, tuberculosis, but also a range of other subjects, including technical innovations in clinical pathology testing. A list of his publications, as recorded in the published Reports from the Laboratory for 19151920 , gives a good idea of the range of his work. ${ }^{8}$

\section{APPLICATION FOR THE CHAIR OF PATHOLOGY IN HONG KONG}

When, in 1919, the University of Hong Kong asked for a recommendation from Edinburgh for someone to fill its first Chair of Pathology, it was no surprise that Wang's name should emerge. In his application for the Chair, submitted to the London Consulting Committee for the University of Hong Kong in May 1919,Wang detailed his experience and his publications, giving as his referees Professor Sir Robert Philip, President of the RCPE, Professor James Lorrain Smith, Professor of Pathology at Edinburgh University (who was also Dean of the Medical School from 1919 to 1931), Professor James Ritchie and Dr Francis Clark, the Dean of the HKCM when Wang was a student and the first Dean of the Medical Faculty of the University of Hong Kong.

Wang was eminently qualified to fill the post, but an unexpected twist to this application process arose when the committee intimated that they did not want a Chinese for the Chair. A less qualified non-Chinese candidate was offered the appointment instead. Although it is possible to interpret this decision by the London Consulting Committee as merely a reflection of the stated aim of the University of Hong Kong at its inception, that is, to provide a 'British' influence in the Far East mainly through the personal influence of its British professorial staff, ${ }^{10}$ not surprisingly the decision and the reason given led to some bad press for the University of Hong Kong.

The London Consulting Committee had been authorised to make appointments by the Acting ViceChancellor, Dr Gregory Jordan, without first consulting the University of Hong Kong Council, which had the ultimate responsibility for making professorial appointments. The Council had obviously been apprised of this extraordinary situation and at first refused to endorse the Senate recommendation and the London Committee action. The impasse was resolved when the first appointee resigned and Wang was offered the appointment instead.

Some circumstances of this controversy came to light from subsequent correspondence between the Foreign Office, the British Minister at Peking and the later Vice- 
Chancellor of the University of Hong Kong, as recorded in Colonial Office Archives." It appears probable that questions had been raised in diplomatic circles, which then provided the catalyst for bringing about the final outcome. Fortunately for Hong Kong and its university, the better qualified person had been given the job. Before leaving Edinburgh in 1920, Wang petitioned successfully for membership of the RCPE and was subsequently elected Fellow in 1923.

\section{THE FOUNDATION CHAIR OF PATHOLOGY}

Wang married his sweetheart Florence Folkard, the daughter of an Edinburgh businessman, in February 1920 and set off on I March 1920 with his bride on the long sea voyage back to Hong Kong. By this time, all medical graduates of Hong Kong University had been granted full registration with the General Medical Council without the need for further examination. Appointment to the Foundation Chair in pathology of Hong Kong's first university, in the faculty which was the continuation of the medical college from which he graduated 12 years earlier, was demanding. Wang laboured for the next ten years to build up his department from scratch, in a new building which had recently been opened as the School of Pathology and School of Tropical Medicine on the main university campus.

True to Edinburgh tradition, he was responsible not only for teaching and research but was also Honorary Consultant in Pathology to the Hong Kong Government, with responsibility for reporting on specimens from the university clinics and wards in the Government Civil Hospital (which was then the main teaching hospital) and for conducting post-mortem examinations on patients who had died in these wards. This tradition still survives in his former department, although it brings about a significantly heavier workload and there is always a struggle to resist the modern trend for separating academic and clinical responsibilities.

In his time, Professor Wang had only one assistant on his staff. As if there was not enough on his plate, he also became acting Government Bacteriologist from 1921 to 1922, when the incumbent, Dr Harold Scott, had to return to England on account of ill health. It was almost unknown at that time for Chinese to be appointed to senior positions in the Hong Kong Government, and this appointment speaks clearly of the high regard in which Wang was held. In the capacity of acting Government Bacteriologist, Wang was in charge of the Government Bacteriological Institute and the Government Mortuary, which served the whole of Hong Kong island. He supervised the production of cowpox, typhoid, rabies and autogenous vaccines, as well as the surveillance of infectious diseases such as plague, together with the reporting on bacteriological, public health and pathological specimens for the whole colony and beyond. ${ }^{12}$ Were it not for the excellent preparation he received while in Edinburgh, it would have been difficult for him to have managed such a diverse range of responsibilities.

While engaging in his many clinical duties Wang took up his teaching responsibilities in an equally serious fashion. One of his former students, then in his nineties, spoke to the author in 1998, remembering Professor Wang as a kind and conscientious teacher interested in the welfare of his students. ${ }^{13}$ In 1925, Wang published a student textbook, Handbook of Pathology, ${ }^{14}$ which was unusual in that the topics were not arranged by the organ systems or by the commonly described pathological processes, but by an aetiological approach in accordance with his own concepts, which he believed was the most helpful approach for his students. This book was dedicated to his Edinburgh teacher, Professor Lorrain Smith.

Wang also built up a teaching collection of museum specimens and microscopic sections; unfortunately the pathology museum was looted and destroyed during the Japanese occupation of 194I-45. He was elected President of the Medical Society of the University of Hong Kong in 1922-23, and later acted as Dean of the medical school in the absence of the Dean. Although this left little time for research, his interest in tuberculosis and laboratory medicine continued. A series of papers was published in The Lancet on different aspects of clinical laboratory testing, ${ }^{15-17}$ and he was also a regular contributor to the Caduceus, a publication of the Medical Society of the University of Hong Kong. Further recognition came when he was nominated in 1929 as a member of the Founding Committee of the Chinese Society of Microbiology in 'Peiping' (now known as Beijing). The Chairman of this committee was no less than DrWu Lien-teh, the famous plague fighter. ${ }^{18}$ There were only two other members of the committee, so we can safely conclude that Wang was among the top few in his profession in the whole of China.

It may be enlightening to compare the careers of $\mathrm{Wu}$ Lien-teh and Chung Yik Wang. Although they worked in different fields of microbiology, both received their medical education in Britain around the same period, and returned to their home countries as pioneers in their respective subjects and developed the disciplines of microbiology and public health in the Far East. In the case of Wang, his was a steady and somewhat selfeffacing labour in the environs of an academic institution, while Wu's career was more colourful, working against the dramatic backdrop of the bleak, frozen environs of Manchuria, fighting to contain a deadly pneumonic plague epidemic and to discover the natural reservoir of the disease. Both were fine scientists, medical professionals and scholars who honed their skills in the laboratories of Europe and brought them back to serve their country. However, whereas Wu lived to enjoy his retirement in his home in Malaya (now Malaysia), Wang's career was 


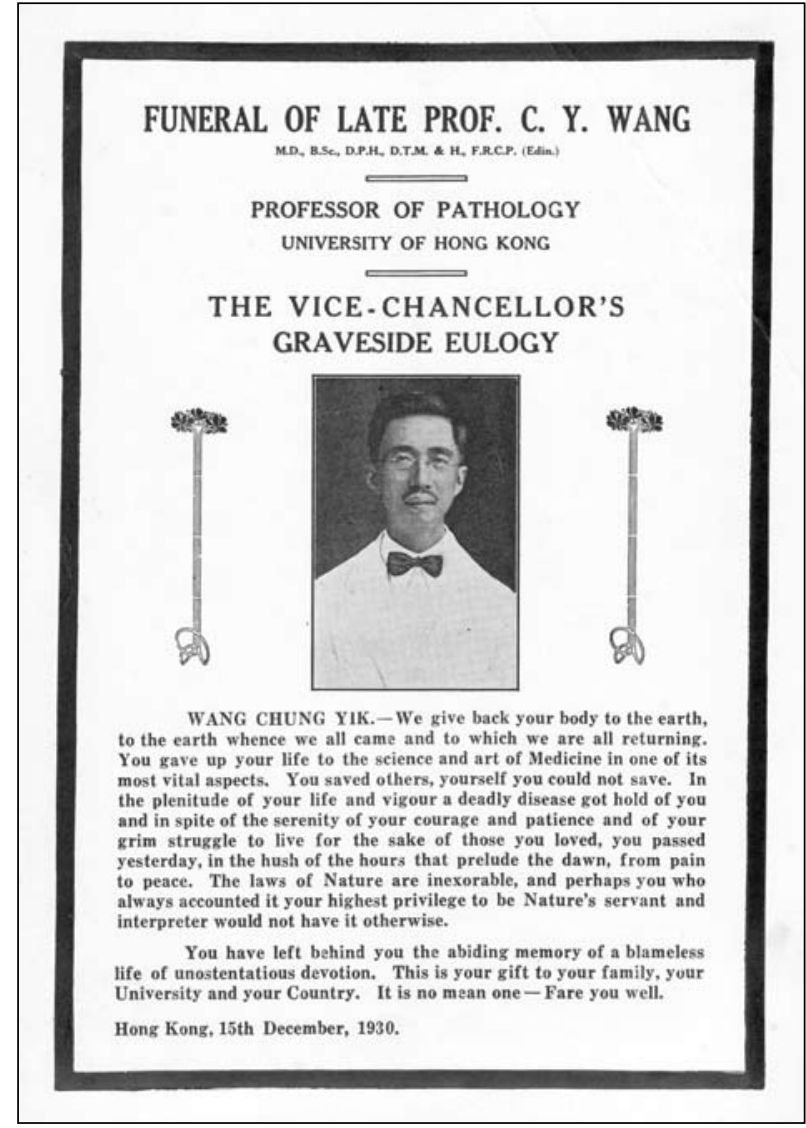

FIGURE 3 The Vice-Chancellor's graveside eulogy for Professor CYWang. (Author's collection.)

cut short tragically at the age of 42 when he succumbed to the disease that he had studied so assiduously. Despite orders from his doctor to rest, he had continued working almost until the end and, when he could no longer lecture on account of tuberculosis affecting his larynx, he wrote down his lectures and had his assistant read them out for him. ${ }^{19}$

There could be few sadder tasks or more poignant messages delivered by a university Vice-Chancellor at the graveside of a colleague than the eulogy delivered on the morning of 15 December 1930, at the graveside of Wang at the Pokfulam cemetery (Figure 3).

Professor Wang left behind his wife and two young sons. They eventually returned to Edinburgh and both sons followed their father's footsteps and graduated from the University of Edinburgh, one in medicine and one in chemistry. Like his father, the late Dr lan Wang was also a Fellow of the RCPE. He generously donated his copy of his father's Handbook of Pathology to the Hong Kong Museum of Medical Sciences, where it is now displayed.

\section{POSTSCRIPT}

The first three decades of the twentieth century in which Wang first trained and then practised medicine were momentous times in the history of the Chinese nation. The twilight years of the failing Qing dynasty, before its overthrow in 1911, were times of tension. On the one hand, there was a desire to preserve Chinese imperial rule and the best features of Chinese civilisation and, on the other, a wish for change coupled with an intense interest in all things Western. Young people especially longed to break from the conservatism and what was perceived as the weakness of the old imperial systems, to gain personal experience and exposure to Western society and the frontiers of scientific knowledge. Hong Kong gave its Chinese population the advantage of an introduction to the West and a glimpse of what it was like, but could not provide the experience in full measure. Even Chinese like Wang, who were Hong Kong born and bred and who had the advantage of the best education Hong Kong had to offer at the time, were still limited by a society constrained by colonial values that tended to discriminate against them.

Many Chinese who were privileged to travel overseas for education and further professional training returned to China to try to bring their new skills and learning to serve and modernise their country. However, the volatile political situation and internal strife of the early period following the fall of the Qing dynasty did not produce the optimal environment for nation building or for technological advances. Nevertheless, due to the change in outlook brought about by the new republic and to the dedication and tenacity of many committed individuals, progress was made.

During this early Chinese Republican period, Hong Kong escaped the brunt of the unrest and presented a relatively peaceful setting, which could have fostered a more steady advancement of knowledge within its institute of higher learning were it not for the lack of funds and the shortage of people who had the potential to advance learning. It is sad to reflect that some of the most promising young academics like Wang did not live to see the fulfilment of their dreams. The writer of Wang's obituary in the Journal of Pathology and Bacteriology summed it up: 'There is no doubt that had his life been spared he would have made his department in Hong Kong University a distinguished centre of teaching and research. ${ }^{20}$ We can only speculate about what might have been.

Acknowledgements I am indebted to lain Milne and Estela Dukan at the RCPE Sibbald Library for their kind assistance when I visited the College library in April 2010 and afterwards. I am also grateful to members of the Wang family for generously sharing with me information about Professor Wang over the years, especially Catherine Wong for the huge effort she made in compiling the chronicles of the family. The Registry of the University of Hong Kong also kindly provided their records of Professor CY Wang to me. The printed copy of the Vice-Chancellor's eulogy was a gift from the late 
Mrs Bek-To King to the author. Tracy Ngai, my research assistant, and the staff of the Hong Kong Museum of Medical Sciences have also provided valuable help over the years. The photograph of Professor Wang, a donation from Dr lan Wang, was provided by the Hong Kong Museum of Medical Sciences Society. This research was partly funded by The Lord Wilson Heritage Trust of Hong Kong.

\section{REFERENCES}

I Ritchie J. History of the Laboratory of the Royal College of Physicians of Edinburgh. Edinburgh: RCPE; 1953. p. 7-15, 52.

2 McCrae M. Physicians and society: a social history of the Royal College of Physicians of Edinburgh. Edinburgh: John Donald; 2007. p. 234-50.

3 Sturdy S. Knowing cases: biomedicine in Edinburgh, 1887-1927. Soc Stud Sci 2007; 37:659-89. doi:I0.II77/03063 I2707076597

4 Lawrence $C$. Rockefeller money, the laboratory, and medicine in Edinburgh 1919-1930. New science in an old country. Rochester, NY: University of Rochester Press; 2005.

5 Fu L. From surgeon-apothecary to statesman: Sun Yat-sen at the Hong Kong College of Medicine. J R Coll Physicians Edinb 2009; 39: 166-72.

6 Letter reproduced in Wong C, editor. The Wongs and Wangs chronicles. Hong Kong: privately published; 2005. p. I74.

7 RCPE Archives. Monthly reports of Superintendent, RCPE Laboratory, 1913-28.

8 Lovell Gulland G, MacKendrick AG, editors. Reports from the Laboratory of the Royal College of Physicians of Edinburgh. Vol. XIV (1915-1920). Edinburgh: RCPE; 1923. p. ix-xi.

9 Wang CY. Letter to the University of Hong Kong London Consultative Committee. Records of the Registry, University of Hong Kong; 1919.

10 Mellor B. Lugard in Hong Kong: empires, education and a governor at work, 1907-19/2. Hong Kong: Hong Kong University Press; I992. p. I74-5.

II Colonial Office Archives, Series 129, File 53I/9 (COI29/53I/9). Correspondence between William Hornell,Vice-chancellor of the University of Hong Kong, Sir William Peel, Governor of Hong Kong and Chancellor of the University, the British Minister in Peking, Sir Miles Lampson, and the Foreign Office, March-April 1931. This correspondence was uncovered through the research of Professor Anthony Sweeting, and kindly drawn to my attention by Catherine Wong.

12 Ho FC. The silent protector, a short centennial history of Hong Kong's Bacteriological Institute. Hong Kong: Hong Kong Museum of Medical Sciences Society; 2006. p.32-56.

13 Personal communication, Dr Yu Chiu-Kwong; 1998.

I4 Wang CY. Handbook of pathology. London: John Bale, Sons and Danielsson; 1925.

15 Wang CY. A precipitation test for syphilis. Lancet 1922; 199:274-6. doi:I0.10I6/S0I40-6736(00)54647-9

16 Wang CY, Basto, RA. Further study of a precipitation test for syphilis. Lancet 1923; 20I:I262-3. doi:I0.10I6/SOI40-6736(00)5485I-X

17 Wang CY. A new culture medium. Lancet 1928; 212:446-7. doi:I0.10I6/S0I40-6736(00)83789-7

I8 Wu Lien-teh. Plague fighter: the autobiography of a modern Chinese physician. Cambridge:W Heffer; 1959.

19 Anon. Obituary: Chung Yik Wang. Caduceus 193I; I0:I-2

20 Anon. Obituary: Chung Yik Wang 1888-1930. J Pathol Bacteriol 1931; 34:189.

\section{I SYMPOSIA}

Palliative care (RCPE/RCGP joint symposium)

Care of the elderly (RCPE/RCGP joint symposium)

Haematology

Maternal medicine (RCPE in association with RCOG)

Stockton symposium: Recent advances in medicine

Infectious diseases

Dermatology

Paediatrics (RCPE/RCPCH joint symposium)

Diabetes

Renal Medicine

Trainees \& Members' Committee symposium

Preston symposium

Neurology (RCPE/RCGP joint symposium)

Cardiology

5 I st St Andrew's Day Festival Symposium:

Update on Acute Medicine
28 March

I April

5 May

2 June

30 June Autumn tbc

2I September

29 September

7 October

13 October 28 October

9 November

16 November

25 November

I-2 December
All symposia are held at the Royal College of Physicians of Edinburgh unless otherwise stated. Further symposia may be added at a later date.

\section{Programme details at:} http://events.rcpe.ac.uk or contact the Symposium Co-ordinator:

Tel: 0I3I 2257324

Email: e.strawn@rcpe.ac.uk

\section{Webstreamed lectures}

If you are unable to attend symposia at the College in Edinburgh, selected lectures from all symposia are available to view and listen to in the Online Education section of the secure area of the College website. There are currently more than 100 lectures covering all the medical specialties and a range of generic topics.

\section{Book online at http://events.rcpe.ac.uk}

